diseases and, where indicated, to increase their efforts to combat, at the national level, the recrudescence of these infections".

\section{Psychiatry in General Practice}

A price has to be paid for evory advance in medicine. With montal disease, for example, an increasing burden is laid on the family doctor by the policy of the "open door'. The wisdom or charity of this new concept of retaining the mentally disturbed patient in the community is generally accepted, aithough the furnily doctor may wonder whethor the enthusiastic progonitors of the concept have ever realized what it moans to him. $\mathrm{He}$ is willing to cope with the situation to the best of his ability, and the airn of a symposium in The Practitioner (194, No. 1163; I965) is to holp him in his onorous task. In the available space only a few aspects of the subject are considered. Those included have boon solected oither bocause they represent conditions commonly oncountered, such as depressive illness which, as Dr. J. Pollitt points out, is the commonest psychiatric condition in general practice, or doal with new developments in this field such as therapeutic communities. The symposium concludes with an article on "The Neurotic in Genoral Practice", which epitomizes one of the most worrying problems facing the family doctor at the present moment. Dr. N. Kessel notes that "Until the theoretical understanding of how to treat neurosis is achievod, until thore is considerably more money to spend within the N.H.S. INational Health Service], the problem of how to manage the mass of neurotic patients known to their doctors cannot be satisfactorily solved". This gloomy outlook is relieved by the evidence that "there is a high proportion of spon. taneous remissions". In other words. "most neurotic patients get better".

\section{The International Hydrological Decade}

Is November 1961, on the authority of the U.S. Depart ment of State, a resolution was tendered to the Executive Board of Unesco ". . . calling attention to the importance of scientific hydrology and recommending that a meeting of experts should be convened, to examine the proposition to institute an international programme for hydrology, extending over a ten-year period". The General Conference of Unesco, in November 1964, approved the plans prepared by meetings of these experts for an International Hydrological Decade, to start in January 1965. The events leading up to this decision have been recorded by $R$. L. Nace in a paper entitled "The International Hydrological Decade" (Trans. Amer. Geophys. Union, 45, $413 ; 1964)$; a later and succinct account of the whole project is contained in an article similarly titled by E. S. Hills (Austral. ,J. Sci., 27, 10; April 1965). This sots forth the main objectives of the scheme, which may be summarized as follows: (a) appraisal of the state of knowledge of world hydrology and identification of the principal gaps in that knowledge; (b) standardization of instruments, observations, techniques and termin. ologies used for compilation and reporting of data; (c) establishment of basic networks and improvements of oxisting networks to provide fundamental data on hydrological systems covering small watersheds to the world as a whole; (d) research on hydrological systoms in selected environments, called 'representative basins'; (e) research on specific hydrological problems tho urgency and special natureof which demand action at international level; ( $f$ ) theoretical and practical training in hydrology and rolated subjects; $(g)$ systematic exchange of information. E. S. Hills is chairman of the Australia-Unesco Committee for the International Hydrological Decade and in his article he gives a brief account of Australian participation in this laudable and vital scheme. This is followod in tho same issue of the Journal by an important paper entitled "Water-Essential Factor of Economic Develop- ment", by R. L. Nace (U.S. (xeological Survey), reproduced from Impact $(14 ; 1964)$; much of the background, both theoretical and technical, of the International Hydrological Decade is disclosed in this essay. The German version of this project is described in an article "Die Internationale Hydrologische Dekade (IHD)" by U. de Haar, Bad Godesborg (Umschau in Wissenschaft und Technik, Frankfurt/M, 14; July 1965); this includes a novel diagram in colour depicting the incidence and passage of rainfall in its circulation on and below the surface of the Earth, what is lost, what is used, and how the inevitable water-cycle is completed.

\section{History under the Sea}

THE Smithsonian Institution has provided a very usoful compondium of the rapidly growing work of underwater oxploration in a book, History under the Sea, by Mendel Peterson (Pp. xiii $+108+56$ plates, publication 4538. Washington, D.C.: Smithsonian Institution, 1965). The subjoct is treatod from all aspocts and oven discusses modern methods of spotting underwater wrecks by magnetometers and induction detectors. A useful section is dovoted to the preservation of materials recovered from the water, both as regards first-aid work in the fiold and subsoquont treatment in the laboratory. A selected bibliography and illustrations of typical finds complete this ominently worth-while publication.

\section{Photography and the Graphic Arts}

There are many publications catoring for the interests of photographers, both amateur and professional, but one entitled Visual is perhaps not so widely known as it deserves to be. Visual is the house organ of Ilford Ltd. (Forguson House, 15-17 Marylebone Road, London, N.W.1), and appears three times annually. Two recent copies (2, No. $3 ; 1964$, and 3 , No. $1 ; 1965$ ) are notable both for contents and certainly for the excellence of the black-and-white and colour illustrations generously distributed throughout the texts, as one would naturally expect from this particular firm. Among the titles in the former issue is "Assignment Tokyo", depicting briefly, in colour, contemporary life in this modern Japanese city; an account of the activities of the Institute of Incorporated Photographers; papers on "Photographic Paper Base", "Medical Photography", and "The Production of Photolitho Printing Surfaces for Offeet Printing". In the more recont issue there are articles on "The Polytechnic Contribution to the Development of Photography"; "Printing and Publishing-15 Years Hence?"; "Photographic Processing Chemicals". The journal also includes an article entitled "Profile: Douglas F. Lawson", dealing with this internationally recognized authority on photomicrography; the colour illustrations to this are quite outstanding, ranging in subject from aspirin crystals, marine-floor foraminifera, natural onyx stone, section of a cat's tongue showing the surface hairs, and the eggs of a moth, to a section of fusod phloridzin, and a reproduction of a slide of Amphioxus, part colour, which demonstrates the value of annotated drawings to accompany photomicrographs. Incidentally, as mentioned in this article, D. F. Lawson is the author of the well-known Technique of Photomicrography; his work ". . . has been reproduced in hundreds of publications in many parts of the world, and used in educational television programmes". $V$ isual is yet another oxample of a high-cless house magazine wheroin advertisement is relegated to a modest background (a brief section entitled "Ilfordia") and the major appeal to the reador made by the quality of its contents, by its inviting format, and especially by its beautiful illustrations.

\section{Creep and Shrinkage of Concrete}

Articles, papers and books dealing with the subject of creep and shrinkage of concrete, held by the library of 
the Cement and Concrete Association, are the basis of a recent publication entitled Annotated Bibliography on the Creep and Shrinkage of Concrete (Pp. 88. London: Cement and Concrete Association, 1965. 20s.). This derives from an extensive literature search on the factors influencing creep and shrinkage and the effect of these functions on concrete as a structural material. The results of this search are presented in three parts: an annotated bibliography of 68 publications; an Appendix (1) comprising a bibliography of more than 800 references to the subject; and an author index (Appendix 2), which greatly facilitates reference to the previous items where their names are known. In the annotated section, the years covered are from 1964 to 1907 (in that order); similarly in Appendix 1, from 1964 to 1868. The scope of this Bibliography is, of course, international, and for architects, civil engineers, cement and concrete technologists, and research students concerned with these problems, its possession will prove not only an invaluable guide to a widely scattered literature, but also a certain time-saver when it comes to reference work.

\section{Anglo-Icelandic Field Research Group}

The Anglo-Icelandic Field Research Group was formed in 1961 to aid and co-ordinate field research in Iceland by specialists, by amateurs and by expeditions. A committee of specialists in geology, botany, ornithology, glaciology and so on deals with requests for information, bibliographies, suggestions for projects, or criticism of plans made. Informal contacts are maintained with Icelandic scientists, and otherwise elusive Icelandic scientific periodicals are subscribed to, thus allowing the most up-to-date information to be given at all times. The Group publishes a Bulletin, of which the third issue, just published, contains news of field work planned for the 1965 and 1966 seasons, brief notes on the progress of work undertaken in 1964, and a comprehensive review of recent scientific literature concerning Icelandic field research topics. Further items in the current issue include a comprehensive general bibliography, notes on information sources and a suggested itinerary for geologists visiting the important volcanic district of Myvatn in north-east Iceland. Further information can be obtained from the secretary of the Group, Mr. P. W. Sowan, 161 Piccadilly, London, W.1.

\section{University News:}

Bristol

DR. L. E. HAwker has been appointed to the chair of mycology. Dr. I. M. Ward has been appointed senior lecturer in the physies of materials in the Department of Physics. The following lecturers have also been appointed: Dr. W. H. H. Banks (mathematics); Dr. B. M. H. Bush (comparative physiology in the Department of Zoology); P. W. Fitt (mechanical engineering); Dr. H. A. Osmaston (geography).

Southampton

Dr. M. H. Quenouille has been appointed to the chair of statistics in the Department of Mathematics. Dr. L. E. Tavener has been appointed reader in geography. The following lecturers have also been appointed: P. W. Fortescue (aeronautics and astronautics); P. C. Ryall (civil engineering); C. B. Chapman (econometries); Dr. A. G. Bailey and Dr. J. A. Coekin (electronics); J. H. Dunmore (mechanical engineering); Dr. P. J. Williams (oceanography); Dr. N. Maclean and Dr. A. E. Wild (zoology).

Swansea

Dr. J. H. Purnell has been appointed professor of physical chemistry. Dr. T. O. Jeffries has been appointed to the newly established chair of industrial engineering. The following appointments have also been made: Senior Lectureships, Dr. E. G. Brown and G. T. Goodman (botany); Dr. J. D. Davies and H. W. Gosling (engineering); Dr. H. E. Hallam (chemistry); Dr. C. N. Linden (pure mathematics); T. S. Walters (applied mathematics); Lectureships, T. H. Walton (pure mathematics); Dr. J. T. Davies and Dr. R. Phythian (physics); Dr. J. H. Williams (chemistry); Dr. D. T. Herbert (geography); Dr. J. S. Ryland (marine biology in the Department of Zoology); Dr. R. A. E. Tilney-Bassett (genetics in the Department of Zoology).

\section{Announcements}

Dr. J. W. Cornforth and Dr. G. J. Popjak, of the Milstead Laboratory of Chemical Enzymology, Shell Research Ltd., have been jointly awarded the first CIBA Medal of the Biochemical Society for their fundamental work on the biosynthesis of cholesterol and the stereospecificity of enzymatic reactions. The Medal will be awarded annually in recognition of outstanding research.

The next awards of the Ethel Behrens Fund of the Chemical Society are to be made in connexion with their anniversary meetings to be held in Oxford in March 1966. This fund provides grants towards travelling and maintenance expenses to help Fellows of the Society studying for a degree at a British university or technical college to attend the anniversary meetings of the society. Application forms and further information can be obtained from the General Secretary, the Chemical Society, Burlington House, London, W.1.

The autumn meeting of the Chemical Society will be held in the University of Nottingham during September 21-22. Further information can be obtained from the General Secretary, the Chemical Society, Burlington House, London, W.1.

A sxMposium on "Reservoir Yield", organized by the Water Research Association, will be held at the University of Oxford during September 21-23. Further information can be obtained from the Water Research Association, Medmenham, Marlow, Bucks.

A conference on "The Fundamentals, Production and Applications of Hard Magnetic Materials" will be held in Vienna during September 21-24. Further information can be obtained from Verein Deutscher Eisenhüttenleute, 4 Düsseldorf, Breite Strasse 27.

A symposium on "Food Science Research in the United Kingdom" will be held at the School of Pharmacy, University of London, on September 22. Further informa. tion can be obtained from the Assistant Secretary, Society of Chemical Industry, 14 Belgrave Square, London, S.W.1.

A symposiom on "Modern Trends in Space Physics", organized by the British Interplanetary Society, will be held at University College, London, on September 23. Further information can be obtained from the Executive Secretary, the British Interplanetary Society, 12 Bess. borough Gardens, London, S.W.1.

A TWO-WEEK summor school on "Methods of Numerical Approximation", organized by the University of Oxford Computing Labcratory and the Delegacy for Extra-mural Studies, will be held in Oxford during September 20 October 1. Further information can be obtained from the Secretary, Delegacy for Extra-mural Studies, Rewley House, Wellington Square, Oxford.

THe fifth international Aerosol Congress and the third International Aerosol Exhibition, organized by the Italian Aerosol Association on behalf of the Federation of European Aerosol Associations, will be held in Milan during September 21-26. Further information can be obtained from the British Aerosol Manufacturers' Association, Cecil Chambers, 86 Strand, London, W.C.2. 